\title{
Application of Dual Coagulant (Alum + Barley) in Removing Colour from Leachate
}

\author{
Nur Shaylinda Mohd Zin ${ }^{1, *}$, Zulazimie Azraff Zulkapli ${ }^{1}$ \\ ${ }^{1}$ Faculty of Civil and Environmental Engineering, Universiti Tun Hussein Onn Malaysia, 86400 Parit \\ Raja, Batu Pahat, Johor, Malaysia
}

\begin{abstract}
Coagulation/ flocculation is one of the treatment method for highly polluted leachate. One of the main affecting factor for this process is the coagulant used. Coagulant is divided into natural and chemical coagulant. In the current study, Alum (chemical coagulant) and barley (natural coagulant) were used as dual coagulant. The aim of this study is to examine the effectiveness of dual coagulant made from alum and barley in removing colour from the effluent of Simpang Renggam landfill leachate aeration lagoon through coagulation/flocculation method. Coagulation/flocculation process with single alum coagulant, single barley coagulant and dual coagulant (alum+barley) were examined by evaluating the optimum values of $\mathrm{pH}$ and dose. Optimum dose and $\mathrm{pH}$ for alum and barley as single coagulant were; $3 \mathrm{~g} / \mathrm{L} \& \mathrm{pH} 5 ; 0.8 \mathrm{~g} / \mathrm{L} \mathrm{\&} \mathrm{pH} \mathrm{6.} \mathrm{Higher}$ removal of colour was recorded for alum compared to barley. Application of alum and barley as dual coagulant had higher colour removal than alum and barley as single coagulant. The optimum $\mathrm{pH}$ and dose for dual coagulant were at $\mathrm{pH} 6,3.0 \mathrm{~g} / \mathrm{L}$ of alum and $0.8 \mathrm{~g} / \mathrm{L}$ of barley respectively. However, at $\mathrm{pH} 6,2 \mathrm{~g} / \mathrm{L}$ alum and $1.6 \mathrm{~g} / \mathrm{L}$ barley, the removal of colour was similar to alum at $3 \mathrm{~g} / \mathrm{L}$. It can be concluded that barley as coagulant aid able to reduce $33 \%$ usage of alum at par removals of colour. Thus, the dual coagulant consist of alum and barley has the potential to be applied as a coagulant for leachate treatment.
\end{abstract}

\section{Introduction}

Increased number of population had causing enormous pressure on the local environment especially in solid waste management. The fast development in industrial sector and improved standard of living produces huge volume of solid waste. In Malaysia, it is a common practice that most of solid waste are disposed by using landfilling method. However the negative outcomes of landfilling is the production of leachate. Leachate is characterised as a highly polluted liquid waste that contains high value of polluted matters such as ammonia, chemical oxygen demand, suspended solid, colour and etc. [1]. Thus, proper treatment of leachate is crucial to maintain a healthy surrounding for living organism.

* Corresponding author: nursha@uthm.edu.my 
There are many methods that can be used to treat this highly contaminated liquid. Basically the treatment of leachate consists of physical, chemical or biological methods. The selection of this treatment method is depending on the maturity of the leachate. One of the treatment methods used is coagulation, which is suitable for intermediate and old leachate [2]. Operation of coagulation is simple yet effective and required small area [3]. One of the main factors that affect coagulation effectiveness is coagulant type. Coagulant used consists of chemical (alum, ferric chloride, poly aluminium chloride) and natural (moringa oleifera, starch, cactus, guar gam) coagulant [4]. It is well known that chemical coagulant is better than natural coagulant. However application of chemical coagulant is exposed to after used effects such as Alzheimer and neuro-degenerative diseases [5]. Furthermore, the cost involved in coagulation is quite expensive for chemical coagulant. Thus, there's a need in finding less expensive and less health effect coagulant. Application of dual coagulant made from natural and chemical coagulant is able to reduce the dose of chemical and reduce the toxicological effect [4]. Successful application of combination coagulant made from natural and chemical coagulant for leachate treatment were proven by Ong, Ramli, Kamaluddin, and Zin et al, [6-9].

Barley is recognised as one of the major crops in daily diets of people [10]. Barley commonly used as animal feed, production of alcoholic beverages and food for human. Barley grain contains starch, fat and fibre components [11]. The starch in barley indicates good coagulant properties and known as natural polymer coagulant [4]. This natural polymer coagulant contains mixture of amylose and amylopectin [12]. The polymer chain structure of the starch, especially the amylopectin improved the coagulation/flocculation ability through bridging mechanism between the branched of the polymer chain [13-14]. However, application of natural polymer as main coagulant is limited by its efficiency in treating high strength wastewater. Thus, the addition of barley as a coagulant aid is seen able to increase the coagulation of the dual coagulant in this study.

Current treatment of Simpang Renggam landfill (SRL) involved aerated lagoon. However, the current treatment is not sufficient to treat the leachate. In order to improve the effluent quality of SRL, this study aimed to examine the effectiveness of dual coagulant made from alum and barley as a coagulant for Simpang Renggam landfill aeration lagoon effluent. The effectiveness of this dual coagulant was measured by determining the percentage removal of colour from SRL aeration lagoon effluent. The optimization of $\mathrm{pH}$ and coagulant dose were tested in this study.

\section{Methodology}

\subsection{Study area and sampling}

Samples of leachate were collected from Simpang Renggam landfill site (SRL) located in Simpang Renggam, Johor, Malaysia. SRL is located at latitude 10 53'41.64" North and longitude 1030 22'34.68' East in Kluang district. The treatment process of leachate in SRL is an aeration lagoon. The leachate samples were taken at the last outlet after leachate was treated by aerated lagoon. Sampling and analytical procedures were conducted in accordance with the American Public Health Association (APHA) Standard Method [15]. Age of SRL is 10 years old and is categorised as an old leachate.

\subsection{Preparation of coagulant}

The alum $\left(\mathrm{Al}_{2}\left(\mathrm{SO}_{4}\right)^{3}\right)$ (3\% concentration) was used as the primary coagulant, while barley ( $1 \%$ concentration) as coagulant aid. Preparation of barley as coagulant was based on 
modification of Okuda et.al study [16]. Dry barley seeds were blended using dry blender. Then, the barley powder was sieved and weighed according to concentration needed (1\% concentration). The barley powder were then added in the beaker containing distilled water. The beaker were stirred using magnetic stirrer and heated up to $90^{\circ} \mathrm{C}$ for 30 minutes. After that, the solution was used as the coagulant aid.

\subsection{Jar test}

Coagulation tests were carried out using a jar test (Flocculator JTL5) apparatus. For this study, only $\mathrm{pH}$ and dose were considered in jar test process. While the factors listed in Table 1 were kept constant. The dose of alum and barley was calculated in $\mathrm{g} / \mathrm{L}$. $\mathrm{NaOH}$ and HCL were used to adjust the $\mathrm{pH}$ of leachate. A $1 \mathrm{~L}$ beaker was filled with $500 \mathrm{~mL}$ of effluent sample of SRL aeration lagoon, followed by the addition of alum under rapid stirring and addition of barley at the start of slow mixing. Then, the leachate was allowed to settle. Finally, $50 \mathrm{~mL}$ supernatant was collected $3 \mathrm{~cm}$ from the surface of the leachate for analysis of the color removal. The control sample was tested in each optimization test. The removal percentage was calculated based on the following formula:

$$
\text { Percentage removal }=\frac{\left(C_{i}-C_{f}\right) \times 100}{C_{i}}
$$

where $C_{i}(m g / L)$ and $C_{f}(m g / L)$ are the initial and final parameter concentration respective.

Table 1. Constant jar test factors.

\begin{tabular}{|c|c|}
\hline Factors & Value \\
\hline Rapid mixing (rpm) & 200 \\
\hline $\begin{array}{c}\text { Rapid mixing duration } \\
\text { (minutes) }\end{array}$ & 4 \\
\hline Slow mixing (rpm) & 30 \\
\hline $\begin{array}{c}\text { Slow mixing duration } \\
\text { (minutes) }\end{array}$ & 15 \\
\hline Settling time (minutes) & 30 \\
\hline
\end{tabular}

Efficiency of dual coagulant (alum+barley) was analysed based on percentage removal of colour from SRL leachate. At the same time, comparison of removal percentage of colour between single alum coagulant, single barley coagulant and dual coagulant was also made.

\section{Results and discussions}

\subsection{Effect of dose}

In this study, colour efficiency of leachate effluent treated by single alum coagulant, single barley coagulant and dual coagulant were compared. As shown in Fig. 1, the colour removal ability of barley is the lowest indicates barley as single coagulant is not effective in removing colour. While alum, as single coagulant records $88 \%$ colour removal at $3.5 \mathrm{~g} / \mathrm{L}$. Application of dual coagulant increased the removal ability. Alum $3 \mathrm{~g} / \mathrm{L}+$ barley and barley $1.6 \mathrm{~g} / \mathrm{L}+$ alum, show higher trends compared to single barley and alum. Thus, addition of barley improved the coagulation process. Barley as coagulant aid, produce better strength 
of floc and increased the weight of the floc and finally increased the colour removal ability [4]. In comparison with Alum $3 \mathrm{~g} / \mathrm{L}+$ barley and barley $1.6 \mathrm{~g} / \mathrm{L}+$ alum, alum $3 \mathrm{~g} / \mathrm{L}+$ barley is better as higher colour removals are recorded. At $3 \mathrm{~g} / \mathrm{L}$ alum and $0.8 \mathrm{~g} / \mathrm{L}$ barley, $98 \%$ colour removal was achieved. At $3 \mathrm{~g} / \mathrm{L}$ alum as single coagulant, just $85 \%$ colour removal was obtained. Therefore, addition of barley increased the colour removal ability. Reduction of alum dose at $1.6 \mathrm{~g} / \mathrm{L}$ barley, achieved slightly low colour removals. However, based on Fig. 1 lower alum dose from 2-2.5 g/L with $1.6 \mathrm{~g} / \mathrm{L}$ barley, has better colour removal compared to alum as single coagulant. Dual coagulant consist of alum $2 \mathrm{~g} / \mathrm{l}$ and barley 1.6 $\mathrm{g} / \mathrm{L}$, achieved $85 \%$ colour removal with alum dose less than $33 \%$ to alum $(3 \mathrm{~g} / \mathrm{L})$ as single coagulant. Based on the results mentioned above, the addition of barley is able to reduce the dose of alum used and improve the coagulation ability. Besides, reduction dose of alum used indicate possible reduction cost of treatment and toxicity effect of the chemical coagulant.

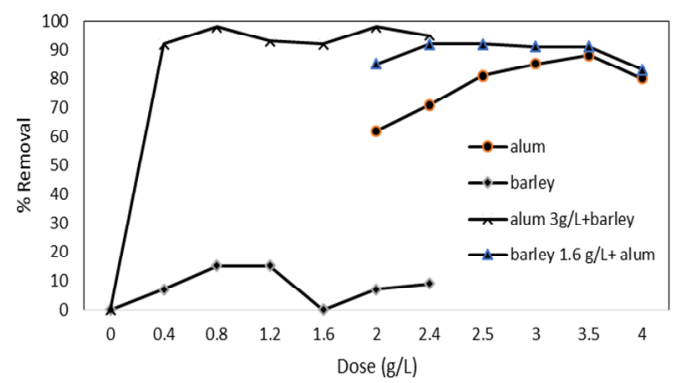

Fig. 1. Effect of dose on color removal.

\subsection{Effect of $\mathrm{pH}$}

The subsequence experiments were designed to find the optimal $\mathrm{pH}$ of dual coagulant (alum $2.5 \mathrm{~g} / \mathrm{L}+$ barley $1.6 \mathrm{~g} / \mathrm{L})$ and compare with single alum $(3 \mathrm{~g} / \mathrm{L})$ and single barley $(0.8$ $\mathrm{g} / \mathrm{L})$. Ability of barley as single coagulant is still the lowest compared to alum and alum+barley. Decolourization of leachate under the influence of $\mathrm{pH}$ at acidic condition, resulted on similar trend for alum, barley and alum+barley. However alum, showed higher removal compared to barley and alum+barley at $\mathrm{pH}$ range 3-5. The amount of alum added was more than amount of barley, so most of the coagulation optimum condition will favoured the optimum condition of alum as a single coagulant. Thus, the difference of percentage removal ability of alum and alum+barley were not too far and this is in line with Chen et. al (2015) study [17]. However, at pH 6 alum+barley, recorded slightly higher removal compared to alum and this indicate a point where the $\mathrm{pH}$ condition is suitable for alum and barley as dual coagulant. Optimum $\mathrm{pH}$ for maximum colour removal efficiencies of alum+barley, alum and barley were at 6,5 and 5, respectively. The colour removal recorded at this optimum $\mathrm{pH}$ for alum+barley, alum and barley were $92 \%, 93 \%$ and $22 \%$, respectively. Lower removals are recorded at alkaline condition for all the coagulant tested as shown in Fig. 2.This instances was in good agreement with the previous finding [9]. The results above indicate that dual coagulant and single alum performed better in acidic condition. 


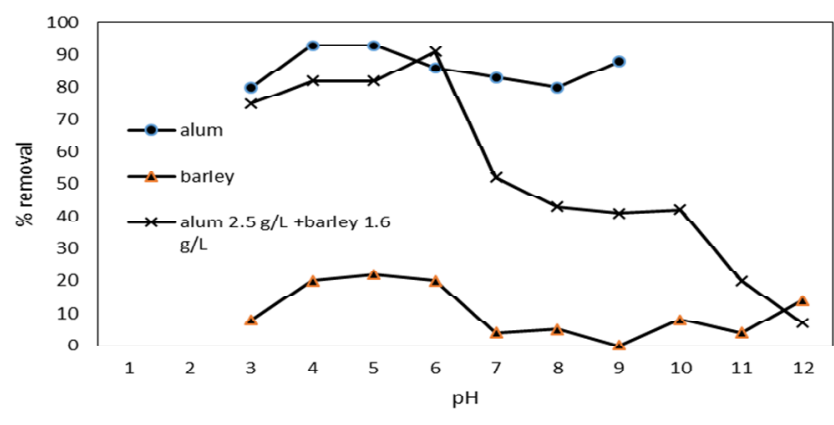

Fig. 2. Effect of $\mathrm{pH}$ on color removal.

\section{Conclusions}

Single alum coagulant, single barley coagulant and dual coagulant (alum+barley) were comparatively investigated in terms of colour removals under the influence of dose and $\mathrm{pH}$. Higher removal of colour was achieved by dual coagulant compared to single alum and barley under the influence of dose. All three coagulants, performed better at acidic condition. However, the best performance was recorded by dual coagulant (alum+barley) at $\mathrm{pH}$, alum $3 \mathrm{~g} / \mathrm{L}$ and barley $0.8 \mathrm{~g} / \mathrm{L}$ with $98 \%$ colour removal. The best color removal of single alum at $\mathrm{pH} 4$, dose $3 \mathrm{~g} / \mathrm{L}$ was $93 \%$. Thus, barley as coagulant aid is able to improve coagulating ability of alum at better $\mathrm{pH}$ and produced higher removal of colour.

The authors would like to gratefully acknowledge Ministry of Higher Education of Malaysia for the research financial support under Fundamental Research Grant Scheme (FRGS) vot NO.1570

\section{References}

[1] N. S. M. Zin, H. Abdul Aziz, M. N. Adlan, A. Ariffin, M. S. Yusoff, I. Dahlan, A comparative study of Matang and Kuala Sembeling landfills leachate characteristics. Applied Mechanics and Materials, 361, 776-781, (2013)

[2] S. Ghafari, H.A. Aziz, M.J. Bashir, The use of poly-aluminum chloride and alum for the treatment of partially stabilized leachate: A comparative study. Desalination, 257(1), 110-116, (2010)

[3] L.M. Rui, Z. Daud, A.A.A. Latif. Treatment of Leachate by Coagulation-Flocculation using different Coagulants and Polymer: A Review. International Journal on Advanced Science, Engineering and Information Technology, 2.2, 114-117, (2012)

[4] N.S.M. Zin, Treatment of Partially Stabilized landfill Leachate using composite coagulant derived from Prehydrolized Iron and Tapioca Starch, PhD. Thesis, Universiti Sains Malaysia, (2015)

[5] S. Bhatia, Z. Othman, A.L. Ahmad, Coagulation-flocculation process for POME treatment using Moringa oleifera seeds extract: optimization studies. Chemical Engineering J., 133 (1), 205-212, (2007)

[6] N. Kamaludin, Kajian penyingkiran kekeruhan, sulfat, nitrat, klorida, cadmium, kuprum dan zink dari air dan air sisa mengunakan kanji semulajadi. Master thesis. University Sains Malaysia, (2005) 
[7] R.Y. Ramli, The use of tapioca starch as coagulant and coagulant aid in leachate treatment, Degree Thesis, Universiti Sains Malaysia, (2011)

[8] S.L. Ong, A study of landfill leachate treatment by PACL, Sago starch and Tapioca starch, Hymenocallis Liriosme and Aloe Vera as coagulant, Master Thesis, Universiti Sains Malaysia, (2010)

[9] N.S.M. Zin, H.A. Aziz, M.N. Adlan, A. Ariffin, M.S. Yusoff, I. Dahlan, Treatability Study of Partially Stabilized Leachate by Composite Coagulant (Prehydrolyzed Iron and Tapioca Flour), Int. J. of Scientific Research in Knowledge 2 (7), 313, (2014)

[10] Tsuij, Hideaki, Masumi Kimoto, and Yasuo Natori. Allergens in major crops. Nutrition Research, 21 (6), 925-934, (2001)

[11]L.D. Campbell, R. J. Boila, S. C. Stothers, Variation in the chemical composition and test weight of barley and wheat grain grown at selected locations throughout Manitoba, Canadian journal of animal science, 75 (2), 239-246, (1995)

[12] Jankowski, A. Jeffrey, T. Calvin, T. Tobison, Starch/cationic polymer combinations as coagulants for the mining industry, U.S. Patent, No. 6,042,732, (2000)

[13]Pérez, Serge, E. Bertoft, The molecular structures of starch components and their contribution to the architecture of starch granules: A comprehensive review, Starch-Stärke, 62 (8), 389-420, (2010)

[14]J. Bratby, Coagulation and flocculation in water and wastewater treatment (IWA publishing, 2006)

[15]APHA, AWWA. WEF Standard methods for the examination of water and wastewater (American Public Health Association, American Water Works Association, and Water Environment Federation, 2005)

[16]Okuda, Tetsuji, Aloysius U. Baes, Wataru Nishijima, and Mitsumasa Okada. Improvement of extraction method of coagulation active components from Moringa oleifera seed, Water research, 33 (15), 3373-3378, (1999)

[17]Chen, Ting, B. Gao, and Q. Yue. Effect of dosing method and $\mathrm{pH}$ on color removal performance and floc aggregation of polyferric chloride-polyamine dual-coagulant in synthetic dyeing wastewater treatment, Colloids and Surfaces A: Physicochemical and Engineering Aspects, 355 (1), 121-129, (2010) 